\title{
A benign ancient schwannoma of the tibia nerve
}

\author{
Sandesh Madi, ${ }^{1}$ Vivek Pandey, ${ }^{1}$ Kirankumar Mannava, ${ }_{1}^{1}$ Kiran Acharya ${ }^{2}$
}

${ }^{1}$ Department of Orthopaedics, Kasturba Medical College Manipal, Manipal, Karnataka, India

${ }^{2}$ Department of Orthopaedics, Manipal University, Manipal, Karnataka, India

\section{Correspondence to} Dr Sandesh Madi, sandesh.madi@gmail.com

Accepted 14 April 2016

\section{DESCRIPTION}

A 46-year-old man, an engineer, presented with chronic left calf pain and tingling sensation in the foot for the past 2 years. There was no history of associated back pain and spine MRI study (performed elsewhere) was essentially normal. Several medics had treated the patient conservatively, yet his symptoms persisted. At the time of presentation, he also pointed out a slow growing swelling in the left popliteal fossa, of 3 months' duration. Clinical examination revealed a small, mobile, nonpulsatile, non-transilluminant, non-tender soft tissue swelling in the popliteal fossa.

Ultrasonography of the popliteal fossa observed a well-defined heterogeneous mass suggestive of a Baker's cyst. In prone position, the popliteal fossa was exposed through a lazy $S$ incision. A firm nodular encapsulated swelling was dissected and found to be adherent to the tibia nerve. Excision was accomplished without dividing the tibia nerve (figure 1). The diagnosis of ancient schwannoma was established by histopathological assessment (figure 2). The patient did not exhibit any neurological deficits in the postoperative period and, at 23 months of follow-up, is symptom-free.

\section{DISCUSSION}

Schwannomas are slow growing painless benign peripheral nerve sheath tumours that are rarely seen to occur in the lower limbs. Clinical presentation is often misleading and ambiguous. The schwannoma of a tibial or sciatic nerve may cause radicular leg pain, which leads to a diagnosis of lumbosacral radiculopathy, chronic regional pain syndrome, tarsal tunnel syndrome, entrapment neuropathies or diabetic neuropathy. ${ }^{1}$ The diagnosis in the index case was overlooked as sonographic evaluation suspected it to be a Baker's cyst-the

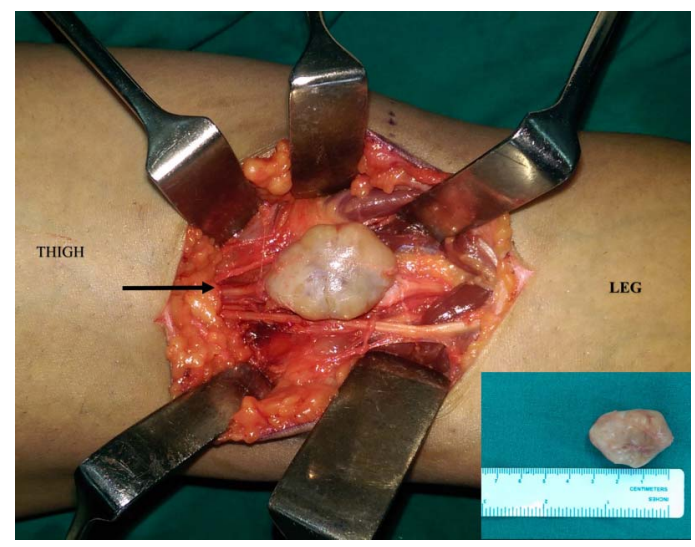

To cite: Madi $S$, Pandey $V_{1}$ Mannava K, et al. BMJ Case Rep Published online: [please include Day Month Year] doi:10.1136/bcr-2016215620
CrossMark

Figure 1 Intraoperative photograph of a schwannoma of the tibia nerve (black arrow) in the popliteal fossa (inset: gross specimen of the excised tumour (nodular and greyish-white)).

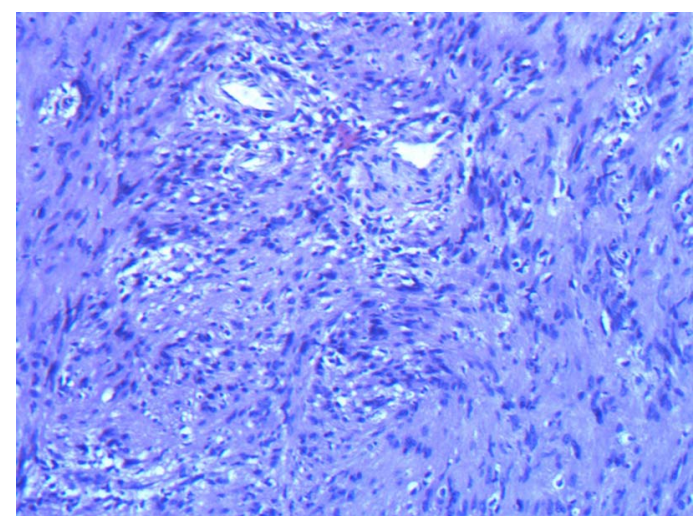

Figure 2 Spindle cells with eosinophilic cytoplasmic processes and palisading forming Verocay bodies. Also seen are congested vessels with perivascular hyalinisation, stromal hyalinisation, haemorrhage and hemosiderin and fibrin deposition (×10; H\&E stain).

most common popliteal swelling-which can occasionally produce compression neuropathy of the tibial nerve.

On sonography, schwannomas appear as welldefined, ovoid, heterogeneous masses in conjunction with cystic degeneration, eccentric location and posterior acoustic enhancement. ${ }^{2}$ MRI is another preferred tool that can define the nervetumour relationship. The lesion presents as a welldefined mass, usually fusiform in shape, located within the nerve, isointense to surrounding muscles on T1-weighted images and hyperintense on T2-weighted images. ${ }^{3}$ Ultrasonography, CT and MRI are all useful modalities in the preoperative diagnostic work up of this nerve tumour, however, each of these imaging studies has limitations in distinguishing between the different types of nerve sheath tumours aside from problems differentiating

\section{Learning points}

- Tibial nerve schwannoma is a rare popliteal fossa swelling with obscure clinical presentation.

- The diagnosis of tibial nerve schwannoma is often established late as it can be mistaken for a radiculopathy or, infrequently, a Baker's cyst producing compression neuropathy.

- On sonography study, based on certain imaging features, this lesion can be reasonably identified or provide a differential diagnosis, however, it can easily be overlooked by the unsuspecting radiologist as well as by clinicians, which can result in intraoperative surprises. 


\section{Images $\ln .$.}

between benign and malignant lesions. Sometimes, longstanding slow growing nerve tumours are known to exhibit degenerative features as seen in the index case. The term 'ancient schwannoma' is used to describe such a rare subset, which can occasionally be misinterpreted as sarcomatous changes. Surgical excision ensures prompt symptomatic relief with a favourable prognosis.

Competing interests None declared.

Patient consent Obtained.
Provenance and peer review Not commissioned; externally peer reviewed.

\section{REFERENCES}

1 Nawabi DH, Sinisi M. Schwannoma of the posterior tibial nerve: the problem of delay in diagnosis. J Bone Joint Surg Br 2007;89:814-16.

2 Pino C, Ghazle H, Bhatt S, et al. Schwannoma of the tibial nerve. J Diagn Med Sonography 2010;26:205-8.

3 Gosk J, Gutkowska O, Urban M, et al. Results of surgical treatment of schwannomas arising from extremities. BioMed Res Int 2015;2015:547926.

Copyright 2016 BMJ Publishing Group. All rights reserved. For permission to reuse any of this content visit

http://group.bmj.com/group/rights-licensing/permissions.

BMJ Case Report Fellows may re-use this article for personal use and teaching without any further permission.

Become a Fellow of BMJ Case Reports today and you can:

- Submit as many cases as you like

- Enjoy fast sympathetic peer review and rapid publication of accepted articles

- Access all the published articles

- Re-use any of the published material for personal use and teaching without further permission

For information on Institutional Fellowships contact consortiasales@bmjgroup.com

Visit casereports.bmj.com for more articles like this and to become a Fellow 